\title{
Highlighting a valuable dimension in health care librarianship: A systematic review
}

\author{
Reza Safdari ${ }^{1}$, Hamideh Ehtesham $^{2 *}$, Leila Bahadori ${ }^{3}$ \\ Received: 16 June 2017 \\ Published: 27 May 2018
}

\begin{abstract}
Background: Educational role is one of the most important roles of librarians, which has taken on wider dimensions. A review of the literature on the training programs provided by librarians revealed an evolution of the ideas and trends in this area. This systematic review aimed at providing a clear image of the available educational programs, their target groups, and the way they are performed.

Methods: This systematic review was done to identify different aspects of the educational role of medical librarians. It was conducted on the studies published in PubMed database during 2005 and 2015. All the studies that described the educational activities of medical librarians were considered for inclusion. All the studies were evaluated by 2 researchers using a checklist, which was developed as an assessment tool. Variables that were considered were as follow: skills taught by librarians, target group, providing training on information resource, teaching method, and session location. After data extraction process and appraisal, the mentioned variables were classified into main categories.
\end{abstract}

Results: A total of 24 studies met the inclusion criteria. The training skills taught by librarians were classified into 3 main groups: information literacy, evidence-based practice, and health literacy. The target groups were library users, patients, and health professionals. Group training was provided, and if necessary, personal training was also offered. Recently, synchronous online training has also been added to the training methods. Most of the training programs are held in classrooms.

Conclusion: By categorizing different aspects of training programs, this study aimed at providing a basis for designing a framework to identify the tasks of educational librarians in health sciences.

Keywords: Librarians, Education, Information literacy, Evidence-based practice, Health literacy

Copyright $\odot$ Iran University of Medical Sciences

Cite this article as: Safdari R, Ehtesham H, Bahadori L. Highlighting a valuable dimension in health care librarianship: A systematic review. Med J Islam Repub Iran. 2018(27 May);32:42. https://doi.org/10.14196/mjiri.32.42

\section{Introduction}

Medical librarians play a wide variety of roles from searching the literature to promoting library services; however, their new roles include attending professional conferences, participating in patient care rounds, performing critical appraisals, and participating in team discussions, ward rounds, and journal clubs (1-4). One of the most influential roles of librarians is their educational role. New developments in the field of information and communication technology (ICT) have radically changed the training programs of libraries, and their new and wider dimensions have been examined in several studies. Instruction has traditionally been an integral part in many programs related to the presence of medical librarians in patient care teams. They have mainly been engaged in

Corresponding author: Dr Hamideh Ehtesham, h-ehtesham@razi.tums.ac.ir

${ }^{1}$ Department of Health Information Management, School of Allied Medical Sciences, Tehran University of Medical Sciences, Tehran, Iran.

2. Birjand University of Medical Sciences, Birjand, Iran. \& Department of Health Information Management, School of Allied Medical Sciences, Tehran University of Medical Sciences, Tehran, Iran.

3. Central Library, Iran University of Medical Sciences, Tehran, Iran. teaching library users how to search for information and identify the related resources and search tools at the point of care (5). Faculty-librarian collaborations are done in various forms, such as single-session and multiple-session courses, workshops, and special courses, and librarian participation in the faculty throughout the whole semester $(6,7)$. The role of health care librarians in supporting the evidence-based practice (EBP) of health care professionals has been documented $(8,9)$. Librarians believe that they can take on such roles as curricular developers, deployers, and assessors in the evidence-based medicine (EBM) curriculum (10). In addition to teaching EBM, librarians have generally played an effective role in planning curricula (11-13), evaluating the performance of

$\uparrow$ What is "already known" in this topic:

One of the most important roles of librarians is their educational role. Moreover, evolution of trends affects the way training programs are provided.

$\rightarrow$ What this article adds:

The present study provided a clear vision of librarians' educational programs, the target groups, and the way they perform to serve the society. 
trainees (14-16), and writing journal papers on EBP training experiences $(15,17,18)$. Information literacy education courses include information about reading and summarizing scientific papers, searching the web and databases, determining appropriate keywords in the search, writing a lab report supported by the primary literature, and writing annotated bibliographies, which are also provided by librarians (19). In recent years, librarians have used innovative methods to fulfill their teaching roles, which have been in contrast with the teaching traditional educator-defined search methods and with using a scenario-based approach to teach information literacy skills to clinicians. This has become an attractive alternative to traditional lectures and teaching methods (20).

A comparison between various strategies of teaching indicates that active learning provides more learning background in a meeting (21). Also, there is a better chance of learning in one shot, face-to-face information skills training sessions provided by librarians than in the methods used by non-library instructors (22).

Various researchers have reviewed and categorized published studies about the educational role of librarians. By conducting a systematic review of the literature on the new roles of health sciences librarians, authors have obtained a list of new roles for them including clinical informationists, bioinformationists, public health informationists, disaster information specialists, systematic review librarians, emerging technologies librarians, continuing medical education librarians, grants development librarians, and data management librarians (23).

A review and comparison of the efficacy of the measures used for assessing library instruction revealed important disparities between the attitudes, skills, and information usage behaviors, but affective measures were not common. Thus, to provide most appropriate evaluation methods, librarians should focus on the accurate assessment of learners' information literacy skills and attitudes (24).

A systematic review of the literature focused on the role of the librarians in teaching EBP. This study revealed that the teaching methods include lectures, small group or oneon-one instruction, computer lab practice, and online learning. EBP instructions are assessed using quizzes or tests, pretests and posttests, peer reviews, search strategy evaluations, clinical scenario assignments, or a hybrid of several of these methods (25).

A review of the coursework and content related to library instruction and iSchools in the United States indicates that medical librarians offer continuing education opportunities for all professionals in the world of the health sciences. Therefore, learning teaching methods and studying instruction methods are necessary in contemporary library and information science (LIS) education (26).

The present study was conducted to analyze the pub- lished researches on the educational role of medical librarians to provide a clear image and a coherent vision of educational programs, their target groups, and the way they are performed.

Three key questions were asked in this study:

1. What information skills are taught in educational programs by medical librarians?

2. Who are the target groups in educational programs taught by medical librarians?

3 . Where the educational programs taught by medical librarians are held and how the programs are administered?

A detailed description about various aspects of the educational role of librarians provides an appropriate model for medical librarians to plan their instructional activities, increase awareness health officials about the expertise of medical librarians, encourage the managers to invite librarians to take part in instructional teams, and attract the attention of policymakers in LIS education to adopt professional and targeted strategies and facilitate the performance of librarians as educators.

\section{Methods}

This study systematically reviewed the articles published in PubMed from 2005 to 2015 to identify those about educational programs provided by medical librarians. Medical Subject Headings (MeSH) was used and the search strategy included all possible combinations of the keywords under 2 broad themes: medical librarian and educational, or training program with the following strategy: ((educational librarian OR medical librarian OR health care librarian OR clinical librarian OR health care Librarianship OR clinical Librarianship OR medical Librarianship OR medical libraries)) AND (education [Title/Abstract] OR training [Title/Abstract] OR educational role [Title/Abstract] OR workshops [Title/Abstract] OR instructional sessions [Title/Abstract]). Filters activated: Humans, English.

Inclusion and exclusion criteria are presented in Table 1 .

Letters, reviews, and conference proceedings were excluded. We screened the titles and abstracts of the retrieved articles to identify and exclude those that were irrelevant. Then, the remaining publications were subjected to the screening of their main content. Also, beforeand-after studies related to articles were investigated and, ultimately, 34 articles met the inclusion criteria and represented the final sample. Studies involved the educational programs that had been performed by medical librarians to make a better use of library services for various target groups. Figure 1 demonstrates the flow of the article selection procedure.

A checklist was developed as an assessment tool to systematically investigate the papers. Variables of the study

Table 1. Inclusion and exclusion criteria in the selection procedure

\begin{tabular}{|c|c|}
\hline Inclusion & Exclusion \\
\hline $\begin{array}{l}\text { Articles that described the educational activities provided by medical librarians } \\
\text { before-and-after studies } \\
\text { Articles published in the last } 10 \text { years }(2005-2015)\end{array}$ & $\begin{array}{c}\text { Non-English language publications } \\
\text { Unavailability of full-text } \\
\text { Similar in content and results with other studies }\end{array}$ \\
\hline
\end{tabular}




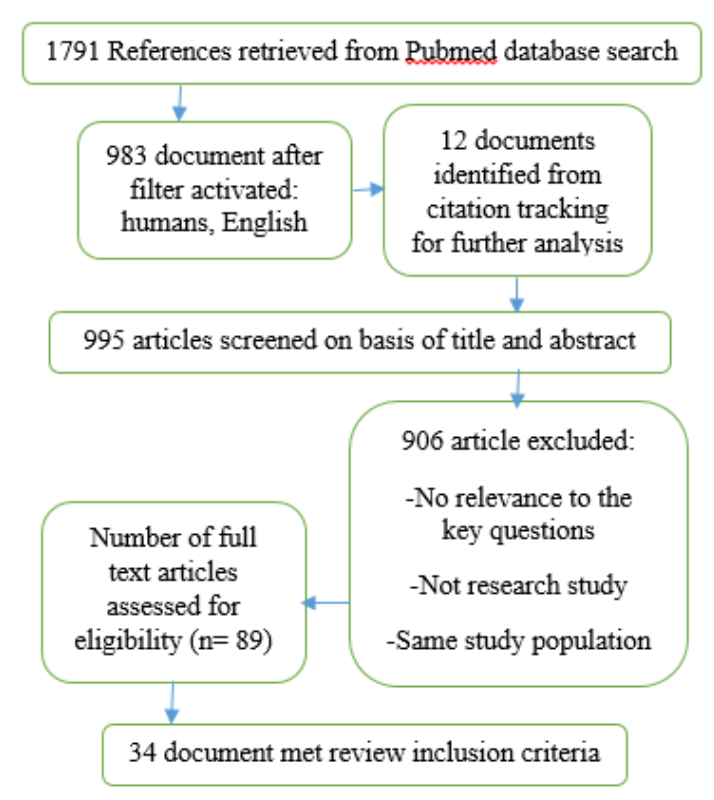

Fig. 1. The flow of the article selection procedure

were associated with information skills training, target groups, information resource training, teaching method, and session location. The articles were evaluated by 2 researchers, then, data extraction and appraisal process were performed based on the checklist.

To organize the data into a coherent form, the variables extracted from the articles were classified into groups.

\section{Results}

A total of 34 articles (ie, those papers written on the instructional activities of medical librarians) met the inclusion criteria. Table 1 demonstrates the characteristics of the included studies. After extracting the full text of the articles, the appraisal process was performed based on the checklist. Table 2 presents the variables extracted from the articles in different groups that were specified after the classification process.

Information skills training: Various studies indicated that librarians have been trained in many skills that can be taught in library facilities, including finding information resources, working with databases, and applying new technologies. In general, the training skills taught by librarians were classified into 3 main groups: information literacy, evidence-based practice, and health literacy.

Target groups and information resource training: The audience of these training programs is widespread, ranging from the users who go to libraries to clinicians who require critical information in clinical settings. Also, patients are increasingly aware of their own conditions and try to learn about their treatment process, which can help improve their health and recovery. Thus, the target audience can be grouped as library users (eg, students, faculty, and researchers), patients, and health professionals. Traditionally, most training programs have been held for students and the content of these courses consisted of teaching library and information retrieval (IR) skills.

Teaching methods: The methods used in training pro- grams include group training (eg, workshops, lectures, and videoconferences) and, if necessary, individual training. Recently, synchronous online training methods have also been used.

Session locations: Based on their purpose, training programs were provided in different places, but most of them had been held in classrooms.

\section{Discussion}

The findings of the present study revealed that development of training programs is one of the most important roles that medical librarians have played over time, and these programs have been provided to a wide range of people with different needs and interests.

Information literacy: Information literacy is a set of abilities requiring individuals to recognize when information is needed and to have the ability to locate, evaluate, and use the needed information effectively(27). Information literacy is the ability to benefit from the information in all forms and includes skills that make effective use of the information. Information may be obtained from any source (print or electronic), and the source of information can also be a person. The development of information and communication technologies has impacted many aspects of life, education, and career. Moreover, achieving information literacy is a requirement and prerequisite for survival in today's knowledge-based society.

Several studies have found that medical librarians are naturally the best candidates for teaching information literacy skills $(28,29)$. The articles reviewed in this study indicate the efforts of librarians to fulfill this role better. In line with the program of information literacy, workshops for MEDLINE searching were held, including the methods of searching for pharmaceutical patents and online guides. Techniques for scoring literature searches and user satisfaction surveys were also evaluated (30). EBM information literacy training sessions were held for students in the form of small groups in collaboration with librarians and faculty members in the computer lab (31). Active learning methods, such as research-based quizzes about famous scientists, were also used to enhance students' learning experiences (32).

To integrate the curriculum and clinical environment, collaborative learning was provided for students and faculty members in the clinical environment. Moreover, the team-based patient care setting and librarians also performed an educational role, with small classes in searching databases or one-on-one instruction. An online subject guide to library resources and services through the website was developed (33).

Another example of training programs by librarians was integration of library training sessions with the curriculum for case-based instruction; moreover, unique cases of virtual patients were included in the software application (34). Medical history seminars were also held to familiarize the students with rare books and special library collections to learn the moral, cultural, and social aspects of medicine and improve their communication skills and skills for tracking diseases over time (35). 


\begin{tabular}{|c|c|c|c|c|}
\hline $\begin{array}{l}\text { Information skill } \\
\text { trained }\end{array}$ & Target group & Information resource trained & Teaching method & Session location \\
\hline Information & Student & literature review process & Program curricula & Online \\
\hline \multirow[t]{19}{*}{ literacy } & & $\begin{array}{l}\text { Information resources relevant } \\
\text { to health careers }\end{array}$ & Videoconference & Library \\
\hline & & EBM information literacy & Small group & Computer lab \\
\hline & & $\begin{array}{l}\text { Reference questions, major } \\
\text { milestones }\end{array}$ & Extracurricular program, short lecture & Classroom \\
\hline & & Information literacy skills & Program curricula & \\
\hline & & MEDLINE searching & Workshops & \\
\hline & & & Curriculum & \\
\hline & & Literature-searching skills & $\begin{array}{l}\text { Curriculum-integrated informat- } \\
\text { ics training }\end{array}$ & \\
\hline & & Library and & Instructional sessions & \\
\hline & & information retrieval (IR) skills & integral to the curriculum & \\
\hline & & & $\begin{array}{c}\text { Research-based quiz } \\
\text { Stand-alone, multi-session }\end{array}$ & \\
\hline & & & library instruction & \\
\hline & & & $\begin{array}{c}\text { Combination of methods (online, } \\
\text { face-to-face and } \\
\text { lecture) }\end{array}$ & \\
\hline & & & Seminar & Library \\
\hline & Library users & & $\begin{array}{l}\text { Combination of methods (in-person, } \\
\text { synchronous online training) }\end{array}$ & Online \\
\hline & Rural clinicians & $\begin{array}{l}\text { Using the hand-held devices to } \\
\text { meet basic information needs }\end{array}$ & Online & \\
\hline & Rural health professionals & Information-seeking Skills & Video instructions & \\
\hline & Students, teachers & $\begin{array}{c}\text { Educational, research, and } \\
\text { patient outcomes }\end{array}$ & $\begin{array}{l}\text { Self-directed learning and research, } \\
\text { combination of methods }\end{array}$ & Clinic \\
\hline & Medical practitioners & $\begin{array}{l}\text { Searching and Appraisal } \\
\text { of medical information }\end{array}$ & Hands-on course & Classroom \\
\hline & Nurses & $\begin{array}{l}\text { Library services and online } \\
\text { resources }\end{array}$ & Workshops & \\
\hline \multirow[t]{8}{*}{$\begin{array}{l}\text { Evidence-based } \\
\text { practice }\end{array}$} & Student & EBM framework & $\begin{array}{c}\text { Collaboration of medical librarian } \\
\text { with the faculty }\end{array}$ & Classroom/clinic \\
\hline & & $\begin{array}{l}\text { Evidence-based Medicine } \\
\text { (EBM) and Evidence-based } \\
\text { dentistry (EBD) courses }\end{array}$ & Interactive online tutorials & Online \\
\hline & & Principles of EBM & Workshop & Library \\
\hline & & EBM PubMed searching skill & Lecture & EBM lab \\
\hline & & & Brief instructional intervention & Classroom \\
\hline & & $\begin{array}{l}\text { EBP cycle, information literacy } \\
\text { competencies }\end{array}$ & $\begin{array}{l}\text { Program curricula (lecture and work- } \\
\text { shop) }\end{array}$ & \\
\hline & & $\begin{array}{l}\text { Evidence-based medicine } \\
\text { (EBM) Literature searching }\end{array}$ & Medical school curriculum & \\
\hline & Nurses and head nurses & $\begin{array}{l}\text { Library and } \\
\text { information Retrieval (IR) } \\
\text { skills }\end{array}$ & $\begin{array}{l}\text { Continuing education programs (lec- } \\
\text { tures and Hands-on training sessions) }\end{array}$ & \\
\hline \multirow[t]{7}{*}{ Health literacy } & Patient & $\begin{array}{c}\text { Educational materials about } \\
\text { diabetes }\end{array}$ & In person & Clinic \\
\hline & & $\begin{array}{c}\text { Self-care during the recovery } \\
\text { period }\end{array}$ & Educational videos & Home viewing \\
\hline & & $\begin{array}{l}\text { Evidence- } \\
\text { based health information }\end{array}$ & Online patient education system & online \\
\hline & & $\begin{array}{l}\text { Patient participation rights in } \\
\text { decision-making }\end{array}$ & Online (web portal) & \\
\hline & & Mental health & Film clubs & Library \\
\hline & Researchers & $\begin{array}{l}\text { Consent form Review service } \\
\text { for principal investigators }\end{array}$ & workshops & \\
\hline & Refugees & $\begin{array}{l}\text { Needed health information, } \\
\text { Emphasizing child health }\end{array}$ & Community conference, focus groups & Home visits \\
\hline
\end{tabular}

Other training courses were held on information literacy for students of dentistry, pharmacy, nursing, and other medical professionals through stand-alone and multisession library instruction courses (36). Training courses on information skills and improvement of global health learning were held in collaboration with Health Sciences Library to prepare students for international experiences. International literature searching skills and countryspecific data sources were also taught in these courses, and the relevant mobile resources were introduced, providing students with a foundation for lifelong learning and the possibility of global engagement (37).

In the project of providing access to health information resources for rural clinicians, librarians played an educational role in training the students to use tools and databases (38). To upgrade services for the disadvantaged and improve their access to the infrastructure of the health information, instructors encouraged them to take on more 
diverse roles. Some educational programs were held in libraries in the form of videoconferences familiarize the students with a range of health professionals, their research interests, related information resources, and health concepts (39).

Some medical libraries hold several extracurricular programs during the year, and the topics of this sessions are determined by librarians based on perceived gaps in the curricula and reference questions from students (40). Some academic health sciences libraries that were providing in-person instruction series to familiarize library users with library services, began to hold synchronous online training for a diverse group of users, including clinicians, researchers, faculty, and remote students. This was done to introduce the changes in library services and resources to provide instruction on basic familiarity with library research, including literature searching skills in scientific databases (such as PubMed, Scopus, and Google Scholar), and different styles of referencing and the use of such tools as EndNote and mobile medical applications (41). An online module was also used to teach the literature review process to the students (42).

Evidence-based practice: Modern medicine is faced with an onslaught of information, especially in the age of communication, and it is difficult to analyze all the published material, even though they are a good source for clinicians. Often researchers publish the results of their research in ways that are not easily accessible to busy medical staff. Thus, there is a need to establish appropriate methods to search, assess, integrate, and review the existing data and produce new data based on previous data.

Evidence-based medicine is the correct, explicit, and judicious use of the best available evidence in making decisions about patient care; moreover, it strives to create a common scientific language for physicians to integrate the best available evidence with their clinical experience and patient values (43). This approach has already been used in several health-related fields, such as nursing, social work, and public health (44). Some of the articles examined in this study revealed that librarians take part in teaching teams to ensure that the physical and occupational therapy graduates acquire the needed skills in using the portions of the EBP cycle. Faculty members and liaison librarians arrange educational activities in the form of lectures, workshops, and assignments to teach the students (45). Specialized training sessions are provided for the following purposes: advanced search, use of filters in the search, and application of $\mathrm{MeSH}$ database during the training courses of EBM PubMed, all of which are held in an EBM lab (11). Other examples of training programs provided by librarians in the form of continuing education programs to promote evidence-based practice of nurses and head nurses (46) include providing training workshops for students in EBM literature searching skills in the library (47), training on the EBM framework through realtime application of EBM skills using actual clinical cases (12), and training on the framework, PICO (problem, intervention, comparison, outcome).

Health literacy: Health literacy is defined as a set of skills to obtain, process, and understand basic health in- formation and have the competence and motivation to use this information to make proper decisions and improve one's own health (48). Health literacy is now seen as an important component of public health. This has attracted the attention of health service providers and policymakers because it plays a significant role in the decision-making of individuals in the fields related to health, promotion of community health, and enhancement of the quality of health care services. Health librarians are forerunners of health literacy training programs.

In line with the programs of health literacy skills and to facilitate consultation with health professionals and librarians in a systematic and transparent way, a web portal was designed in which the principal steps of evidence-based performance, critical evaluation of information, and patients' rights to participate in the decision-making process have been explained (49).Various educational tools have been used to promote health literacy skills. For example, film clubs have been set up with the aim of teaching and learning about mental health (50). Librarians have also taught academic researchers how to write a consent form for participants in research studies. By communicating transparently with researchers, librarians have played an important role in the research efforts of universities (51). By providing educational materials to patients with chronic diseases, librarians have also had an influential role in informing these patients about their diseases, which have led to improvement in health care (52). To raise the awareness of the local health and social service providers of the refugees, a service innovation was developed. Training programs were developed based on the needs of refugees, which were identified using focus groups and community conference techniques. The required health information was taught through home visits, with an emphasis on the health of children (53).

This study was a snapshot of the educational role of librarians at a given period and clearly revealed that medical librarians teach a wide range of skills to different groups in the form of various training programs. Although these activities have a long history, librarians have begun to play a more active educational role in helping their clients locate the information they need, especially in the case of scientific analysis and new subject areas. Future studies can include other communities and different time periods to increase the knowledge of the training programs performed by librarians. Increased attention to these training programs will provide more opportunities for authorities and target groups to realize and benefit from the potential contribution of medical librarians. The findings of this study may guide new developments in the instructional activities of medical librarians and may also help develop educational programs to prepare them for this role.

\section{Conclusion}

One of the most important and useful activities of medical librarians is to provide training programs that have been tailored to the needs of target groups in different ways. By categorizing different aspects of the training programs, this study presents a structured view of all as- 
pects of librarians' role, providing the groundwork to include medical librarians in the educational teams and sometimes in the clinical fields. It seems that similar to clinical librarians, who have an established place in the scope of medical librarianship, we will see the rise of educational librarians in the near future. This study provides a clear image of various aspects of the educational role of librarians, and it can also be used as a basis to design a framework for describing the position and tasks of educational librarians in health sciences.

\section{Acknowledgments}

We would like to thank the library staff of Tehran University of Medical Sciences for their sincere cooperation and for helping us obtain better results in searching the articles.

\section{Conflict of Interests}

The authors declare that they have no competing interests.

\section{References}

1. Brettle A, Maden-Jenkins M, Anderson L, McNally R, Pratchett T, Tancock J, et al. Evaluating clinical librarian services: a systematic review. Health Info Libr J. 2011;28(1):3-22.

2. Cimpl K. Clinical medical librarianship: a review of the literature. Bull Med Libr Assoc. 1985;73(1):21-8.

3. Giuse NB, Kafantaris SR, Miller MD, Wilder KS, Martin SL, Sathe NA, et al. Clin Med librariansh: Vanderbilt Exp. Bull Med Libr Assoc. 1998;86(3):412-6.

4. Harrison J, Beraquet V. Clinical librarians, a new tribe in the UK: roles and responsibilities. Health Info Libr J. 2010;27(2):123-32.

5. Tan MC, Maggio LA. Expert searcher, teacher, content manager, and patient advocate: an exploratory study of clinical librarian roles. J Med Libr Assoc. 2013;101(1):63-72.

6. Fuselier L, Nelson B. A test of the efficacy of an information literacy lesson in an introductory biology laboratory course with a strong science-writing component. Sci Technol Libr. 2011;30(1):58-75.

7. York AC, Vance JM. Taking library instruction into the online classroom: Best practices for embedded librarians. J Libr Adm. 2009;49(1-2):197-209.

8. Jenkins M, Johnson F. Awareness, use and opinions of methodological search filters used for the retrieval of evidence-based medical literature - a questionnaire survey. Health Info Libr J. 2004;21(1):33-43.

9. Rodrigues RJ. Information systems: the key to evidence-based health practice. Bull World Health Org. 2000;78(11):1344-51.

10. Maggio LA, Durieux N, Tannery NH. Librarians in Evidence-Based Medicine Curricula: A Qualitative Study of Librarian Roles, Training, and Desires for Future Development. Med Ref Serv Q. 2015;34(4):428-40.

11. Eldredge JD, Bear DG, Wayne SJ, Perea PP. Student peer assessment in evidence-based medicine (EBM) searching skills training: an experiment. J Med Libr Assoc. 2013;101(4):244-51.

12. Gagliardi JP, Stinnett SS, Schardt C. Innovation in evidence-based medicine education and assessment: an interactive class for third- and fourth-year medical students. J Med Libr Assoc. 2012;100(4):306-9.

13. Morley SK, Hendrix IC. "Information Survival Skills": a medical school elective. J Med Libr Assoc. 2012;100(4):297-302.

14. Carlock D, Anderson J. Teaching and assessing the database searching skills of student nurses. Nurse Educ. 2007;32(6):251-5.

15. Maranda S. Bringing the scholar competency to life: learning and assessment. J Can Health Libr Assoc. 2014;34(1):24-8.

16. Stark R, Helenius IM, Schimming LM, Takahara N, Kronish I, Korenstein D. Real-time EBM: from bed board to keyboard and back. J Gen Intern Med. 2007;22(12):1656-60.

17. Boruff JT, Thomas A. Integrating evidence-based practice and information literacy skills in teaching physical and occupational therapy students. Health Info Libr J. 2011;28(4):264-72.

18. Dinkevich E, Markinson A, Ahsan S, Lawrence B. Effect of a brief intervention on evidence-based medicine skills of pediatric residents. BMC Med Educ. 2006;6(1):1.

19. Thompson L, Blankinship LA. Teaching information literacy skills to sophomore-level biology majors. J Microbiol Biol Educ. 2015;16(1):29-33.

20. Pettersson J, Bjorkander E, Bark S, Holmgren D, Wekell P. Using scenario-based training to promote information literacy among oncall consultant pediatricians. J Med Libr Assoc. 2017;105(3):262-7.

21. Johnson HA, Barrett L. Your teaching strategy matters: how engagement impacts application in health information literacy instruction. J Med Libr Assoc. 2017;105(1):44-8.

22. Mery Y, Newby J, Peng K. Why one-shot information literacy sessions are not the future of instruction: A case for online credit courses. Coll Res Libr. 2011:crl-271.

23. Cooper ID, Crum JA. New activities and changing roles of health sciences librarians: a systematic review, 1990-2012. J Med Libr Assoc. 2013;101(4):268-77.

24. Schilling K, Applegate R. Best methods for evaluating educational impact: a comparison of the efficacy of commonly used measures of library instruction. J Med Libr Assoc. 2012;100(4):258-69.

25. Swanberg SM, Dennison CC, Farrell A, Machel V, Marton C, O'Brien KK, et al. Instructional methods used by health sciences librarians to teach evidence-based practice (EBP): a systematic review. J Med Libr Assoc. 2016;104(3):197-208.

26. Detlefsen EG. Teaching about teaching and instruction on instruction: a challenge for health sciences library education. J Med Libr Assoc. 2012;100(4):244-50.

27. Iannuzzi P. Information literacy competency standards for higher education. J Community Jr Coll Libr. 2000; 9(4)

28. Moniz Jr RJ, Eshleman J, Jewell D, Mooney B, Tran C. The impact of information literacy-related instruction in the science classroom: Clickers versus nonclickers. Coll Undergrad Libr. 2010;17(4):34964.

29. Rinto EE, Cogbill-Seiders EI. Library Instruction and Themed Composition Courses: An Investigation of Factors That Impact Student Learning. J Acad Librariansh. 2015;41(1):14-20.

30. Clairoux N, Desbiens S, Clar M, Dupont P, St-Jean M. Integrating information literacy in health sciences curricula: a case study from Quebec. Health Info Libr J. 2013;30(3):201-11.

31. McClurg C, Powelson S, Lang E, Aghajafari F, Edworthy S. Evaluating effectiveness of small group information literacy instruction for Undergraduate Medical Education students using a pre- and post-survey study design. Health Info Libr J. 2015;32(2):120-30.

32. Flint L. 'Letting them loose!' A different approach to a biochemistry post-exam training session. Health Info Libr J. 2013;30(1):83-7.

33. Simons MR, Morgan MK, Davidson AS. Time to rethink the role of the library in educating doctors: driving information literacy in the clinical environment. J Med Libr Assoc. 2012;100(4):291-6.

34. Rafferty RS. The impact of library instruction: do first-year medical students use library resources specifically highlighted during instructional sessions? J Med Libr Assoc. 2013;101(3):213-7.

35. Shedlock J, Sims RH, Kubilius RK. Promoting and teaching the history of medicine in a medical school curriculum. J Med Libr Assoc. 2012;100(2):138-41.

36. Le ML. The use of anonymous pop-quizzes (APQs) as a tool to reinforce learning. J Med Libr Assoc. 2012;100(4):316-9.

37. Rana GK. Information empowerment: predeparture resource training for students in global health. J Med Libr Assoc. 2014;102(2):101-4.

38. Wallace RL, Woodward NJ, Clamon TS. A mixed-methods analysis of a library-based hand-held intervention with rural clinicians. Health Info Libr J. 2014;31(3):215-26.

39. Locatis C, Gaines C, Liu WL, Gill M, Ackerman M. Lessons learned from ten years of distance learning outreach. J Med Libr Assoc. 2015;103(2):78-82.

40. Swanberg SM, Engwall K, Mi M. Continuing education for medical students: a library model. J Med Libr Assoc. 2015;103(4):203-7.

41. Smith SC, O'Hagan EC. Taking library instruction into the online environment: one health sciences library's experience. J Med Libr Assoc. 2014;102(3):196-200.

42. Newall E, Gratton C, Maltby J. 'Today and more than ever, I feel like a researcher': successful online learning collaborations between 
librarians and a Graduate School. Health Info Libr J. 2014;31(2):167-71.

43. Sackett DL, Rosenberg WM, Gray JA, Haynes RB, Richardson WS Evidence based medicine: what it is and what it isn't. BMJ (Clin Res Ed). 1996;312(7023):71-2.

44. Satterfield JM, Spring B, Brownson RC, Mullen EJ, Newhouse RP, Walker BB, et al. Toward a transdisciplinary model of evidencebased practice. Milbank Q. 2009;87(2):368-90.

45. Boruff JT, Thomas A. Integrating evidence-based practice and information literacy skills in teaching physical and occupational therapy students. Health Info Libr J. 2011;28(4):264-72.

46. Ovaska T. Making evidence-based decisions when organising information retrieval training for nurses and head nurses. Health Info Libr J. 2012;29(3):252-6.

47. Ilic D, Tepper K, Misso M. Teaching evidence-based medicine literature searching skills to medical students during the clinical years: a randomized controlled trial. J Med Libr Assoc. 2012;100(3):190-6

48. Kasemsap K. The Fundamentals of Health Literacy. Medical Education and Ethics: Concepts, Methodologies, Tools, and Applications: Concepts, Methodologies, Tools, and Applications. 2016:1.

49. Austvoll-Dahlgren A, Danielsen S, Opheim E, Bjorndal A, Reinar LM, Flottorp S, et al. Development of a complex intervention to improve health literacy skills. Health Info Libr J. 2013;30(4):278-93.

50. Gorring H, Loy J, Spring H. Cinemeducation: using film as an educational tool in mental health services. Health Info Libr J. 2014;31(1):84-8

51. Raimondo PG, Harris RL, Nance M, Brown ED. Health literacy and consent forms: librarians support research on human subjects. J Med Libr Assoc. 2014;102(1):5-8

52. Koonce TY, Giuse NB, Kusnoor SV, Hurley S, Ye F. A personalized approach to deliver health care information to diabetic patients in community care clinics. J Med Libr Assoc. 2015;103(3):123-30.

53. Eisenhauer ER, Mosher EC, Lamson KS, Wolf HA, Schwartz DG. Health education for Somali Bantu refugees via home visits. Health info Libr J. 2012;29(2):152-61. 